\title{
Rheinheimera longhuensis sp. nov., isolated from a slightly alkaline lake, and emended description of genus Rheinheimera Brettar et al. 2002
}

Correspondence

Zhi-Pei Liu

liuzhp@sun.im.ac.cn

\author{
Ying Liu, ${ }^{1} \dagger$ Jia-Tong Jiang, ${ }^{1} \dagger$ Cheng-Jun $\mathrm{Xu},{ }^{2}$ Ying-Hao Liu, ${ }^{1}$ \\ Xue-Feng Song, ${ }^{2}$ Hao $\mathrm{Li}^{2}$ and Zhi-Pei Liu ${ }^{1}$
${ }^{1}$ State Key Laboratory of Microbial Resources, Institute of Microbiology, Chinese Academy of Sciences, Beijing 100101, PR China
${ }^{2}$ Water Supply Company of Daqing Petroleum Administration, No. 49, Aiguo Road, Ranghulu District, Daqing 163453, PR China

The genus Rheinheimera, a branch of the gammaproteobacteria, was created by Brettar et al. (2002) and its description has subsequently been emended by Merchant et al. (2007), Chen et al. (2010) and Li et al. (2011). At the time of writing, the genus Rheinheimera comprises ten recognized species: Rheinheimera baltica (the type species; Brettar et al., 2002), R. pacifica (Romanenko et al., 2003), R. perlucida (Brettar et al., 2006), R. aquimaris (Yoon et al., 2007), R. texasensis (Merchant et al., 2007), R. chironomi (Halpern et al., 2007), R. soli (Ryu et al., 2008), R. tangshanensis (Zhang et al., 2008), R. aquatica (Chen et al.,

†These authors contributed equally to this work.

The GenBank/EMBL/DDBJ accession number for the 16S rRNA gene sequence of strain LH2-2 ${ }^{\top}$ is EU183319.

Five supplementary figures and a supplementary table are available with the online version of this paper.
2010) and R. nanhaiensis (Li et al., 2011). Members of Rheinheimera have mostly been isolated from aquatic environments (except for $R$. soli, $R$. nanhaiensis and $R$. tangshanensis, which were isolated from soil, marine sediments and plant roots, respectively), including seawater (R. baltica, R. pacifica, R. perlucida and R. aquimaris) and freshwater $(R$. texasensis, $R$. aquatica and $R$. chironomi; the latter was isolated from a chironomid egg mass sampled from river water). Species of Rheinheimera are able to grow on and to degrade rapidly the more easily degradable organic fraction of marine organic matter (Bianchi \& Bianchi, 1995; Pinhassi \& Berman, 2003; Poretsky et al., 2005), suggesting that they may play important roles in aquatic environments in biogeochemical cycling of elements such as carbon. In this communication, a freshwater bacterial isolate capable of growth at $0{ }^{\circ} \mathrm{C}$, strain $\mathrm{LH} 2-2^{\mathrm{T}}$, was investigated for its taxonomic position by a polyphasic approach. 
Strain LH2-2 ${ }^{\mathrm{T}}$ was isolated from surface water of a slightly alkaline lake, Longhu Lake (46 $46^{\prime} 47.0^{\prime \prime} \mathrm{N} 124^{\circ} 26^{\prime} 11.1^{\prime \prime} \mathrm{E}$; maximum depth $3 \mathrm{~m}, 12{ }^{\circ} \mathrm{C}$, chemical oxygen demand $80 \mathrm{mg} \mathrm{l}^{-1}, \mathrm{pH} \mathrm{8.8)}$ in Daqing, Heilongjiang Province, China, during the study of the bacterial diversity of the freshwater in this lake in 2008. For isolation, serially tenfolddiluted water samples were spread onto low-organic LuriaBertani (LOLB) agar (containing $1.0 \mathrm{~g}$ tryptone, $0.5 \mathrm{~g}$ yeast extract and $10.0 \mathrm{~g} \mathrm{NaCl} 1^{-1}, \mathrm{pH} \mathrm{8.0)}$ and incubated at $30{ }^{\circ} \mathrm{C}$ for 2 days. Strain $\mathrm{LH} 2-2^{\mathrm{T}}$ was obtained after several streakings and transfers on LOLB agar plates, and it could also grow well on normal Luria-Bertani agar and marine 2216 agar (MA; Difco); the strain grew slowly on R2A agar.

All experiments were performed in parallel on strain LH2$2^{\mathrm{T}}$ and type strains of species of the genera Rheinheimera and Alishewanella, except for morphological studies and DNA G + C content analyses.

Routine cultivation was conducted at $30{ }^{\circ} \mathrm{C}$ with $\mathrm{MA}$ ( $\mathrm{pH}$ 8.0) unless otherwise indicated. Gram staining was performed according to Gerhardt et al. (1994). Endospore formation was tested by malachite green staining (Dong \& Cai, 2001). Flagellation was examined by transmission electron microscope (H-600; Hitachi) after negative staining with $1 \%(\mathrm{w} / \mathrm{v})$ phosphotungstic acid. Morphological observations were carried out using a scanning electron microscope (FEI Quanta 2000). The growth temperature range was determined with a TN3F temperature-gradient incubator (Advantec) and results were recorded after 2 and 7 days. The $\mathrm{pH}$ range for growth $(\mathrm{pH} 5.0-11.5)$ was tested in marine 2216 broth (MB; Difco) (inoculum size $0.01 \%$ ) with the $\mathrm{pH}$ adjusted by addition of $5 \mathrm{M} \mathrm{NaOH}$ or $\mathrm{HCl}$ and adjusted again with sterile $\mathrm{NaOH}$ or $\mathrm{HCl}$ after autoclaving.

Tolerance of $\mathrm{NaCl}$ was examined in modified $\mathrm{MB}$ (laboratory prepared) with final $\mathrm{NaCl}$ concentrations of 0 $2.5 \%(\mathrm{w} / \mathrm{v})$ (at intervals of $0.5 \%)$. Physiological and biochemical tests, including catalase and oxidase activity, hydrolysis of casein, starch and Tweens 20 and 80, indole production and nitrate reduction, were carried out according to Dong \& Cai (2001). Oxygen requirement was determined by incubation in an Oxoid AnaeroGen system. Anaerobic respiration tests were performed as described by Brettar et al. (2002) in MB using thiosulfate, sulfite, nitrate and ferric iron as electron acceptors. Formation of $\mathrm{H}_{2} \mathrm{~S}$ from thiosulfate was tested with lead acetate paper. Some carbon source utilization tests were performed according to the methods of Dong \& Cai (2001); further carbon source utilization tests were performed using API $50 \mathrm{CH}$ test strips (bioMérieux) according to the manufacturer's instructions. Strain LH2-2 ${ }^{\mathrm{T}}$ was also characterized by using API $20 \mathrm{NE}$ and API ZYM systems (bioMérieux) following the manufacturer's instructions. Susceptibility to antibiotics was determined by the agar diffusion method using filter-paper discs (Beijing Pharmaceutical Company) containing various antibiotics as specified in the species description.

Strain $\mathrm{LH} 2-2^{\mathrm{T}}$ was heterotrophic, aerobic and oxidaseand catalase-positive. No growth occurred under anoxic conditions, even in the presence of the tested electron acceptors. Cells were Gram-staining-negative, non-sporeforming rods, $0.3-0.5 \mu \mathrm{m}$ wide and $2.0-4.0 \mu \mathrm{m}$ long, and motile by means of a single polar flagellum (Fig. S1, available in IJSEM Online). Colonies were $1-2 \mathrm{~mm}$ in diameter, smooth, non-pigmented, transparent, raised and circular with entire margins after cultivation on MA ( $\mathrm{pH}$ 8.0) for 24 h. Strain $\mathrm{LH} 2-2^{\mathrm{T}}$ grew at $0-36{ }^{\circ} \mathrm{C}, \mathrm{pH}$ 6.5-11 and in the presence of $0-2 \% \mathrm{NaCl}(\mathrm{w} / \mathrm{v})$, with optimal growth at $26-$ $34{ }^{\circ} \mathrm{C}, \mathrm{pH} 8.0-8.6$ and $1.0 \% \mathrm{NaCl}(\mathrm{w} / \mathrm{v})$. No growth was observed at -1 or $37{ }^{\circ} \mathrm{C}$ or at $\mathrm{pH} 6.0$ or 11.5. More physiological and biochemical properties of strain LH2-2 ${ }^{\mathrm{T}}$ are provided in Table 1 as well as in the species description.

Biomass for chemotaxonomic analyses was cultivated on MA at $30{ }^{\circ} \mathrm{C}$ for $24 \mathrm{~h}$. Cellular fatty acids were analysed using the standard MIDI Sherlock Microbial Identification System (version 6.0), and peaks were identified on an Agilent 6890N Network GC system using the peak-naming table TSBA6. Isoprenoid quinones were extracted and purified according to the method of Collins (1985) and analysed by HPLC (Wu et al., 1989), with a previously characterized mixture of various menaquinones and ubiquinones ( $\mathrm{Hu}$ et al., 2004) as a reference. Polar lipids were extracted using a chloroform/methanol system and identified using two-dimensional TLC, as described by Kates (1986). Merck silica-gel $60 \mathrm{~F}_{254}$ aluminium-backed thin-layer plates were used in TLC analysis. The major fatty acids of strain $\mathrm{LH} 2-2^{\mathrm{T}}$ were summed feature $3\left(\mathrm{C}_{16: 1} \omega 7 \mathrm{c}\right.$ and/or iso- $\left.\mathrm{C}_{15: 0} \quad 2-\mathrm{OH} ; 21.9 \%\right), \mathrm{C}_{17: 1} \omega 8 \mathrm{c} \quad(18.9 \%)$, $\mathrm{C}_{18: 1} \omega 7 c(16.4 \%)$ and $\mathrm{C}_{16: 0}(12.7 \%)$. Strain LH2-2 ${ }^{\mathrm{T}}$ had a fatty acid profile similar to those of the type strains of the most closely related Rheinheimera and Alishewanella species under the same cultivation conditions (Table S1). All strains had summed feature 3 and $\mathrm{C}_{16: 0}$ as dominant fatty acids. The major isoprenoid quinone of strain $\mathrm{LH} 2-2^{\mathrm{T}}$ was Q-8 $(>95 \%)$. The results shown in Fig. S2 indicate that all tested members of the genera Rheinheimera and Alishewanella exhibited quite similar polar lipid profiles. All tested strains contained phosphatidylglycerol and phosphatidylethanolamine as the major polar lipids, and some unknown phospholipids and aminolipids as minor polar lipids. In comparison with its closest relative, $R$. pacifica NBRC $103167^{\mathrm{T}}$, strain $\mathrm{LH} 2-2^{\mathrm{T}}$ contained one more unknown aminolipid (AL3) and lacked one unknown phospholipid (PL3), in addition to phosphatidylglycerol and phosphatidylethanolamine (Fig. S2).

The nearly complete $16 \mathrm{~S}$ rRNA gene of strain LH2-2 ${ }^{\mathrm{T}}$ (1488 nt) was amplified and sequenced as described by Zhang et al. (2003). The 16S rRNA gene sequence was then compared with available 16S rRNA gene sequences in GenBank databases using the BLAST program (Altschul et al., 1990) at NCBI (http://www.ncbi.nlm.nih.gov). Alignments of $16 \mathrm{~S}$ rRNA gene sequences were performed with the CLUSTAL_X program (version 1.64b; Thompson et al., 1997) and then phylogenetic analyses were carried out using three treeing algorithms, the neighbour-joining (Saitou \& Nei, 1987), maximum-parsimony (Fitch, 1971) 
and maximum-likelihood (Felsenstein, 1981) methods. The neighbour-joining tree reconstructed with Kimura's twoparameter model and the pairwise-deletion option in MEGA version 3.1 (Kumar et al., 2004) is shown in Fig. 1. Two major clusters, corresponding to the genera Rheinheimera and Alishewanella, can be observed. Strain LH2-2 ${ }^{\mathrm{T}}$ belonged to the Rheinheimera cluster (95.3-97.4\% sequence similarity), with the highest sequence similarity to $R$. pacifica KMM $1406^{\mathrm{T}}(97.4 \%)$ and R. aquimaris SW- $353^{\mathrm{T}}$ (97.1\%). Species belonging to the genus Alishewanella formed a distinct cluster and were closely related to the Rheinheimera species. Strain $\mathrm{LH} 2-2^{\mathrm{T}}$ also showed high sequence similarity to members of the genus Alishewanella (96.3-97.1\%), with the highest sequence similarity to Alishewanella aestuarii $\mathrm{B} 11^{\mathrm{T}}$ (97.1\%). The maximum-parsimony (Fig. S3) and maximum-likelihood (Fig. S4) trees showed almost the same topologies as the neighbour-joining tree.

The gyrB gene (encoding gyrase B) has also been used in phylogenetic analyses of related bacteria, such as the genus Alishewanella (Fonnesbech Vogel et al., 2000) and Pseudomonas putida strains (Yamamoto \& Harayama, 1995). In this study, a conserved fragment of gyrB (approx. $1200 \mathrm{nt}$ ) from strain LH2-2 ${ }^{\mathrm{T}}, R$. tangshanensis CGMCC $1.6362^{\mathrm{T}}, R$. aquimaris $\mathrm{JCM} 14331^{\mathrm{T}}, R$. perlucida LMG $23581^{\mathrm{T}}, R$. chironomi LMG $23818^{\mathrm{T}}$ and $R$. pacifica NBRC $103167^{\mathrm{T}}$ was amplified and sequenced as described by Fonnesbech Vogel et al. (2000) and Yamamoto \& Harayama (1995). An unrooted neighbour-joining tree based on gyrB sequences (Fig. S5) indicated that members of the genus Alishewanella formed a distinct cluster in the tree, with high sequence similarities $(>91.4 \%)$ to each other. However, members of the genus Rheinheimera formed two distinct clusters, and $\mathrm{LH} 2-2^{\mathrm{T}}$ displayed quite low gyrB sequence similarities to members of the genera Rheinheimera (73.9-77.7\%) and Alishewanella (76.2$78.7 \%$ ). These results further suggested that $\mathrm{LH} 2-2^{\mathrm{T}}$ is a member of the genus Rheinheimera.

DNA base composition was determined by thermal denaturation (Marmur \& Doty, 1962), with DNA from Escherichia coli $\mathrm{K}-12$ as a reference. The DNA G+C content of strain LH2-2 ${ }^{\mathrm{T}}$ was $47 \mathrm{~mol} \%\left(T_{\mathrm{m}}\right)$, within the range of values reported for the genus Rheinheimera (47.0 $50.5 \mathrm{~mol} \%)$.

Strain $\mathrm{LH} 2-2^{\mathrm{T}}$ showed some important properties that are in agreement with those reported for the genus Rheinheimera but different from the properties of members of the genus Alishewanella, such as being strictly aerobic (in particular, no growth under anoxic conditions even in the presence of electron acceptors), flagellated and not requiring $\mathrm{NaCl}$ for growth, being able to assimilate $\mathrm{N}$ acetylglucosamine and malate and showing $N$-acetyl- $\beta$ glucosaminidase activity. However, strain $\mathrm{LH} 2-2^{\mathrm{T}}$ also showed a range of phenotypic characteristics that differentiated it from currently described Rheinheimera species (Table 1), such as the ability to grow at $0{ }^{\circ} \mathrm{C}$, nitrate reduction, assimilation of various carbon resources and production of different enzymes. To distinguish strain LH $2-2^{\mathrm{T}}$ further from closely related Rheinheimera species, DNA-DNA hybridization was performed by using the initial renaturation rate method of De Ley et al. (1970) and modified by $\mathrm{Huß}$ et al. (1983). Results showed that the DNA-DNA relatedness of strain $\mathrm{LH} 2-2^{\mathrm{T}}$ to $R$. pacifica NBRC $103167^{\mathrm{T}}$, R. aquimaris JCM $14331^{\mathrm{T}}$ and R. chironomi LMG $23818^{\mathrm{T}}$ was 39,31 and $23 \%$, respectively.

Combining the above results of phenotypic, chemotaxonomic and genotypic studies, it is concluded that strain $\mathrm{LH} 2-2^{\mathrm{T}}$ represents a novel species of the genus Rheinheimera, for which the name Rheinheimera longhuensis sp. nov. is proposed. An emended description of the genus Rheinheimera is also provided.

\section{Emended description of the genus Rheinheimera Brettar et al. 2002}

The description is as given by Brettar et al. (2002) and emended by Merchant et al. (2007), Chen et al. (2010) and Li et al. (2011) with the following additional changes. Growth occurs at $0-43{ }^{\circ} \mathrm{C}$. The major polar lipids are phosphatidylglycerol and phosphatidylethanolamine.

\section{Description of Rheinheimera longhuensis sp. nov.}

Rheinheimera longhuensis (long.hu.en'sis. N.L. fem. adj. longhuensis pertaining to Longhu Lake, from which the organism was first isolated).

Heterotrophic, aerobic, oxidase- and catalase-positive. Cells are Gram-staining negative, non-spore-forming rods, $0.3-0.5 \mu \mathrm{m}$ wide and $2.0-4.0 \mu \mathrm{m}$ long, motile by means of a single polar flagellum. Colonies are $1-2 \mathrm{~mm}$ in diameter, smooth, non-pigmented, transparent, raised and circular with entire margins after cultivation on MA $(\mathrm{pH}$ 8.0) for 24 h. Grows at $0-36{ }^{\circ} \mathrm{C}$ (optimum, $26-34{ }^{\circ} \mathrm{C}$ ) and $\mathrm{pH}$ 6.511 (optimum, $\mathrm{pH} 8.0-8.6$ ) and in the presence of $0-2 \%$ (w/v) $\mathrm{NaCl}$ (optimum, 1\%). Positive for hydrolysis of starch, casein, Tweens 80 and 20 and DNA. Utilizes methionine, L-glutamic acid, valine, asparagine and DLlysine. Negative for $\mathrm{H}_{2} \mathrm{~S}$ production. According to API $20 \mathrm{NE}$ and API $50 \mathrm{CH}$ tests, positive for nitrate reduction, hydrolysis of aesculin and gelatin and assimilation of Dglucose, maltose, malate, trehalose, D-fructose, $\mathrm{N}$-acetylglucosamine, aesculin, cellobiose, sucrose, starch and glycogen; all other test results are negative. In API ZYM analysis, the following enzyme activities are detected: acid and alkaline phosphatases, esterase (C4), esterase lipase (C8), leucine arylamidase, valine arylamidase, trypsin, $\alpha$-chymotrypsin, naphthol-AS-BI-phosphohydrolase, $N$ acetyl- $\beta$-glucosaminidase and cystine arylamidase (weakly positive). Major cellular fatty acids when grown on MA are summed feature $3\left(\mathrm{C}_{16: 1} \omega 7 c\right.$ and/or iso- $\left.\mathrm{C}_{15: 0} 2-\mathrm{OH}\right)$, $\mathrm{C}_{17: 1} \omega 8 c, \mathrm{C}_{18: 1} \omega 7 c$ and $\mathrm{C}_{16: 0}$. The major quinone is $\mathrm{Q}-8$. The DNA G + C content of the type strain is $47 \mathrm{~mol} \%$ $\left(T_{\mathrm{m}}\right)$. The polar lipids consist of phosphatidylglycerol, phosphatidylethanolamine, two unknown phospholipids 
Table 1. Properties of strain $\mathrm{LH} 2-2^{\top}$ and members of the genera Rheinheimera and Alishewanella

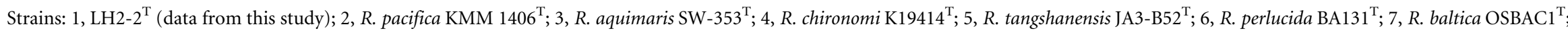

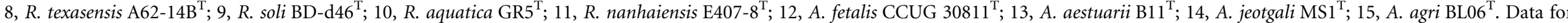
reference strains are from Romanenko et al. (2003), Yoon et al. (2007), Halpern et al. (2007), Zhang et al. (2008), Brettar et al. (2002, 2006), Merchant et al. (2007), Ryu et al. (2008), Chen et al. (2010), Li et al. (2011), Fonnesbech Vogel et al. (2000), Roh et al. (2009) and Kim et al. (2009, 2010) unless indicated. All strains are positive for catalase and oxidase activities, hydrolysis of gelatin, starch and Tween 80 and API ZYM tests for alkaline phosphatase and leucine arylamidase; all strains are negative for hydrolysis of L-arginine, indole production, fermentation of D-glucose, assimilation of mannose, gluconate, caprate, adipate and phenylacetate and API ZYM tests for lipase (C14), $\beta$-galactosidase, $\beta$-glucuronidase, $\alpha$-mannosidase and $\alpha$-fucosidase. + , Positive; - , negative; w, weakly positive; NR, not reported.

\begin{tabular}{|c|c|c|c|c|c|c|c|c|c|c|c|c|c|c|c|}
\hline Characteristic & 1 & 2 & 3 & 4 & 5 & 6 & 7 & 8 & 9 & 10 & 11 & 12 & 13 & 14 & 15 \\
\hline Source of isolation & $\begin{array}{l}\text { Lake } \\
\text { water }\end{array}$ & $\begin{array}{l}\text { Deep } \\
\text { seawater }\end{array}$ & Seawater & $\begin{array}{c}\text { Chironomid } \\
\text { egg mass }\end{array}$ & $\begin{array}{l}\text { Rice } \\
\text { roots }\end{array}$ & $\begin{array}{l}\text { Surface } \\
\text { seawater }\end{array}$ & $\begin{array}{l}\text { Surface } \\
\text { seawater }\end{array}$ & Lake water & Soil & $\begin{array}{l}\text { Freshwater } \\
\text { pond }\end{array}$ & $\begin{array}{l}\text { Marine } \\
\text { sediments }\end{array}$ & $\begin{array}{c}\text { Human } \\
\text { fetus }\end{array}$ & $\begin{array}{l}\text { Tidal flat } \\
\text { sediment }\end{array}$ & $\begin{array}{l}\text { Fermented } \\
\text { food }\end{array}$ & $\begin{array}{c}\text { Landfill } \\
\text { soil }\end{array}$ \\
\hline Pigmentation & None & None & $\begin{array}{c}\text { Yellowish } \\
\text { white }\end{array}$ & None & None & None & Blue & None & None & $\begin{array}{c}\text { Greenish } \\
\text { yellow }\end{array}$ & $\begin{array}{l}\text { Slightly } \\
\text { yellow }\end{array}$ & None & None & Ivory & None \\
\hline Cell width $(\mu \mathrm{m})$ & $0.3-0.5$ & $0.6-0.8$ & $0.3-0.7$ & $0.3-0.7$ & $0.4-1.0$ & $0.6-1.2$ & $0.5-1.5$ & $0.7-0.8$ & $0.9-1.5$ & $0.5-1.0$ & $0.3-0.5$ & $0.5-1.0$ & NR & 1 & 0.5 \\
\hline Cell length $(\mu \mathrm{m})$ & $2.0-4.0$ & $1.8-2.0$ & $0.3-5.0$ & $1.0-2.4$ & $1.3-2.5$ & $0.9-2.4$ & $0.9-2.5$ & $1.25-2.5$ & $2.0-3.5$ & $1.5-2.0$ & $1.0-2.0$ & 2 & NR & $2-6$ & $1-2$ \\
\hline Flagella* & $\mathrm{S}, \mathrm{P}$ & $\mathrm{M}, \mathrm{P}$ and $\mathrm{L}$ & S, P & $\mathrm{S}, \mathrm{P}$ & $S$, P or $L$ & $\mathrm{~S}, \mathrm{P}$ & S, P & $\begin{array}{l}\mathrm{S}, \mathrm{P} \text { or } \mathrm{M}, \mathrm{P} \\
\text { and } \mathrm{L}\end{array}$ & S, P & S, P & S, P & None & S, P & S, P & None \\
\hline Oxygen requirement $\dagger$ & A & A & A & A & A & FAN & A & FAN & FAN & A & FAN & FAN & NR & FAN & A \\
\hline \multicolumn{16}{|l|}{$\begin{array}{l}\text { Growth temperature } \\
\left({ }^{\circ} \mathrm{C}\right)\end{array}$} \\
\hline Range & $0-36$ & $4-37$ & $4-43$ & $4-40$ & $10-37$ & $4-37$ & $4-30$ & $25-37$ & $15-35$ & $10-40$ & $10-48$ & $25-42$ & $18-44$ & $4-40$ & $10-44$ \\
\hline Optimum & $26-34$ & $25-30$ & $30-37$ & $30-37$ & 30 & $20-30$ & $20-25$ & $30-37$ & $25-30$ & 35 & 37 & 37 & 37 & NR & NR \\
\hline \multicolumn{16}{|l|}{$\begin{array}{l}\text { Growth in } \mathrm{NaCl} \\
(\%, w / v)\end{array}$} \\
\hline Range & $0-2$ & $0-8$ & $0-8$ & $0-2$ & $0-3$ & $0-8$ & $0-6$ & $0-1$ & $0-4$ & $0-2.0$ & $0-8$ & $1-8$ & $0-5$ & $1-2$ & $0-6$ \\
\hline Optimum & 1 & $0.5-2.5$ & $1-3$ & $0.5-1$ & 1 & $1-3$ & $1-3$ & 0 & $0-1$ & $0.5-1.0$ & $0.5-2.5$ & $\mathrm{NR}$ & 3 & $\mathrm{NR}$ & $\mathrm{NR}$ \\
\hline \multicolumn{16}{|l|}{$\mathrm{pH}$ for growth } \\
\hline Range & $6.5-11$ & $5.5-10.5$ & $5.5-10.5$ & $6.5-10.0$ & $6.0-8.5$ & $5.7-10$ & $5.7-10$ & $6.5-9.6$ & $6.5-8.0$ & $7.0-8.0$ & $5.5-10.0$ & NR & NR & $6.5-9.0$ & $5.5-12$ \\
\hline Optimum & $8.0-8.6$ & $5 \quad 8.0-8.5$ & $7.0-8.0$ & $7.5-8.0$ & 7.0 & 7.0 & 7.0 & $7.5-8.0$ & $7.0-7.5$ & 8.0 & $7.5-8.5$ & $\mathrm{NR}$ & $\mathrm{NR}$ & NR & NR \\
\hline Nitrate reduction & + & -‡ & $+\ddagger$ & $+末$ & $-\ddagger$ & + & - & + & + & + & + & $+\ddagger$ & $+\ddagger$ & $+\ddagger$ & $+\ddagger$ \\
\hline Hydrolysis of aesculin & + & + & + & - & + & - & + & + & + & + & + & - & - & + & + \\
\hline \multicolumn{16}{|l|}{ Assimilation of: } \\
\hline D-Glucose & + & $+\ddagger$ & $-\ddagger$ & $+末$ & $+\ddagger$ & - & + & + & + & + & + & $-\ddagger$ & -末 & $+\ddagger$ & $+\ddagger$ \\
\hline L-Arabinose & - & $+\ddagger$ & $-\ddagger$ & $-\ddagger$ & $+\ddagger$ & - & - & + & + & - & - & $-\ddagger$ & $-\ddagger$ & $-\ddagger$ & $-\ddagger$ \\
\hline Mannitol & - & $-\ddagger$ & $-\ddagger$ & $-\ddagger$ & $-\ddagger$ & - & - & - & - & - & - & $+\ddagger$ & $-\neq$ & $-\ddagger$ & $-\ddagger$ \\
\hline Maltose & + & $+\ddagger$ & $+\ddagger$ & $+末$ & $+\ddagger$ & - & + & - & + & + & + & $+\ddagger$ & $+\ddagger$ & $+\ddagger$ & $+\ddagger$ \\
\hline Malate & + & $-\ddagger$ & $-\ddagger$ & $+\neq$ & $+\ddagger$ & - & - & - & - & - & - & $-\ddagger$ & $-末$ & $-\ddagger$ & $-\ddagger$ \\
\hline Citrate & - & $+\ddagger$ & $-\ddagger$ & $-\ddagger$ & $-\ddagger$ & - & - & - & - & - & - & $-\ddagger$ & $-\ddagger$ & $-\ddagger$ & $-\ddagger$ \\
\hline$N$-Acetylglucosamine & + & $+\ddagger$ & $+\ddagger$ & $+\neq$ & $+\ddagger$ & + & + & + & + & + & + & $-\ddagger$ & 一未 & $-\neq$ & $-\neq$ \\
\hline
\end{tabular}


Table 1. cont.

\begin{tabular}{|c|c|c|c|c|c|c|c|c|c|c|c|c|c|c|c|}
\hline Characteristic & 1 & 2 & 3 & 4 & 5 & 6 & 7 & 8 & 9 & 10 & 11 & 12 & 13 & 14 & 15 \\
\hline \multicolumn{16}{|l|}{ API ZYM test results } \\
\hline Esterase (C4) & + & $+\ddagger$ & $+\ddagger$ & $+\ddagger$ & $+\ddagger$ & + & - & + & + & - & + & $+\ddagger$ & $+\ddagger$ & $+\ddagger$ & $+末$ \\
\hline Esterase lipase (C8) & + & $+\ddagger$ & $+\ddagger$ & $+\neq$ & $+\ddagger$ & + & - & + & + & + & + & $+\ddagger$ & $+\ddagger$ & $+\ddagger$ & $+\ddagger$ \\
\hline Valine arylamidase & $\mathrm{w}$ & $-\ddagger$ & $-\ddagger$ & $\mathrm{w} \ddagger$ & $-\ddagger$ & - & - & - & - & - & + & $+\ddagger$ & $-\ddagger$ & $-\ddagger$ & $-\ddagger$ \\
\hline Cystine arylamidase & $\mathrm{w}$ & $-\ddagger$ & $-\ddagger$ & $\mathrm{w} \ddagger$ & $-\ddagger$ & - & - & + & - & - & - & $+\ddagger$ & $w \ddagger$ & $-\ddagger$ & $\mathrm{W} \ddagger$ \\
\hline Trypsin & + & $+\ddagger$ & $-\ddagger$ & $+\ddagger$ & $+\ddagger$ & + & + & + & + & + & + & $+\ddagger$ & $+\ddagger$ & $+\ddagger$ & $+\ddagger$ \\
\hline$\alpha$-Chymotrypsin & + & $+\ddagger$ & $-\ddagger$ & $+\ddagger$ & $-\ddagger$ & + & - & + & + & + & + & $+\ddagger$ & $+\ddagger$ & $+\ddagger$ & $+\ddagger$ \\
\hline Acid phosphatase & + & $+\ddagger$ & $+\ddagger$ & $+\ddagger$ & $+\ddagger$ & + & - & + & $\mathrm{w}$ & + & + & $+\ddagger$ & $\mathrm{W} \ddagger$ & $w \ddagger$ & $\mathrm{W} \ddagger$ \\
\hline $\begin{array}{l}\text { Naphthol-AS-BI- } \\
\text { phosphohydrolase }\end{array}$ & + & $+\ddagger$ & $+\ddagger$ & $+\ddagger$ & $+\ddagger$ & + & + & + & + & - & + & $+\ddagger$ & $+\ddagger$ & $+\ddagger$ & $+\ddagger$ \\
\hline$\alpha$-Galactosidase & - & $-\ddagger$ & $-\ddagger$ & $-\ddagger$ & $-\ddagger$ & - & - & - & $\mathrm{W}$ & - & - & $-\ddagger$ & $-\ddagger$ & $-\ddagger$ & - \\
\hline$\alpha$-Glucosidase & - & $-\ddagger$ & $-\ddagger$ & $-\ddagger$ & $-\ddagger$ & - & - & - & $\mathrm{w}$ & - & - & $-\ddagger$ & $-\ddagger$ & -末 & $-末$ \\
\hline$\beta$-Glucosidase & - & $-\ddagger$ & $-\ddagger$ & $-\ddagger$ & $-\ddagger$ & - & + & - & - & - & - & $-\ddagger$ & $-\ddagger$ & $+\ddagger$ & $-\ddagger$ \\
\hline $\begin{array}{l}N \text {-Acetyl- } \beta \text { - } \\
\text { glucosaminidase }\end{array}$ & + & $+\ddagger$ & $+\ddagger$ & $+\ddagger$ & $+\ddagger$ & + & + & + & + & + & + & $-\ddagger$ & $-\neq$ & -‡ & $-\ddagger$ \\
\hline $\begin{array}{l}\text { DNA G + C content } \\
(\mathrm{mol} \%)\end{array}$ & 47 & 49.6 & 50.5 & 49.9 & 47.0 & 48.9 & 48.9 & 48.2 & 49.2 & 51.9 & 51.0 & 51 & 49.5 & 53.6 & 54.8 \\
\hline
\end{tabular}

${ }^{\star} \mathrm{L}$, Lateral; M, multiple; $\mathrm{P}$, polar; $\mathrm{s}$, single.

$\dagger$ A, Aerobic; FAN, facultatively anaerobic.

$\ddagger$ Results from this study. 


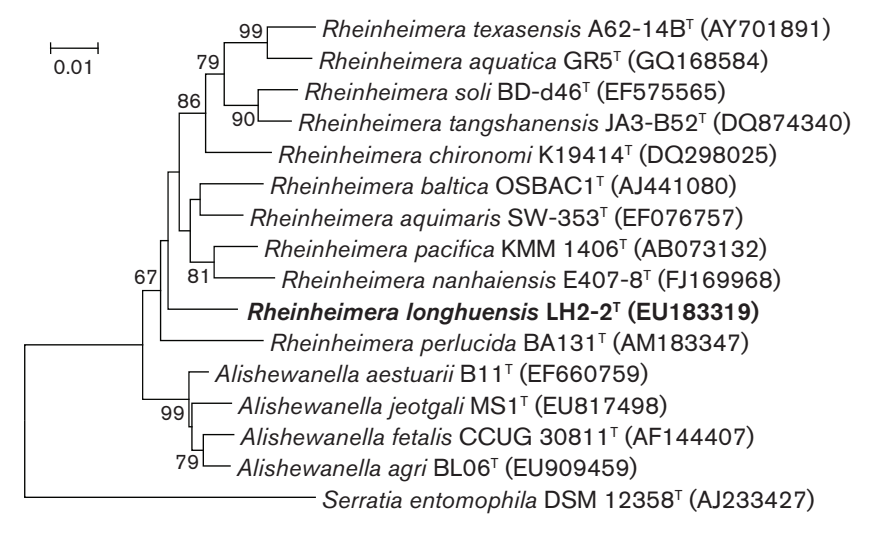

Fig. 1. Neighbour-joining tree based on $16 \mathrm{~S}$ rRNA gene sequences showing the phylogenetic position of strain $\mathrm{LH}_{2}-2^{\top}$ and members of related species. Bootstrap values (expressed as percentages of 1000 replications) $>50 \%$ are shown at branch points. Serratia entomophila DSM $12358^{\top}$ was used as an outgroup. Bar, evolutionary distance $\left(K_{\text {nuc }}\right)$ of 0.01 .

and three unknown aminolipids. Susceptible (diameter of inhibition zone $>20 \mathrm{~mm}$ ) to ( $\mu \mathrm{g}$ per disc unless indicated) gentamicin (10), kanamycin (30), chloramphenicol (30), ampicillin (10), tetracycline (30), neomycin (30) and carbenicillin (100). Weakly resistant (diameter of inhibition zone $10-20 \mathrm{~mm}$ ) to streptomycin (10), polymyxin (300) and novobiocin (5). Resistant (diameter of inhibition zone $<10 \mathrm{~mm}$ ) to bacitracin (1 U) and vancomycin (30).

The type strain is $\mathrm{LH} 2-2^{\mathrm{T}}$ (=CGMCC $1.7003^{\mathrm{T}}=\mathrm{NBRC}$ $105632^{\mathrm{T}}$ ), isolated from surface water of Longhu Lake in north-east China.

\section{Acknowledgements}

This work was supported by grants from the Hi-Tech Research and Development Program of China '863' program (2006AA06Z316) and the Knowledge Innovation Program of the Chinese Academy of Sciences (KSCS2-YW-G-055-01).

\section{References}

Altschul, S. F., Gish, W., Miller, W., Myers, E. W. \& Lipman, D. J. (1990). Basic local alignment search tool. J Mol Biol 215, 403410.

Bianchi, A. \& Bianchi, M. (1995). Bacterial diversity and ecosystem maintenance: an overview. In Microbial Diversity and Ecosystem Maintenance, pp. 185-198. Edited by D. L. Hawksworth \& R. R. Colwell. Wallingford, UK: CAB International.

Brettar, I., Christen, R. \& Höfle, M. G. (2002). Rheinheimera baltica gen. nov., sp. nov., a blue-coloured bacterium isolated from the central Baltic Sea. Int J Syst Evol Microbiol 52, 1851-1857.

Brettar, I., Christen, R. \& Höfle, M. G. (2006). Rheinheimera perlucida sp. nov., a marine bacterium of the Gammaproteobacteria isolated from surface water of the central Baltic Sea. Int J Syst Evol Microbiol 56, 2177-2183.
Chen, W. M., Lin, C. Y., Young, C. C. \& Sheu, S. Y. (2010). Rheinheimera aquatica sp. nov., an antimicrobial activity producing bacterium isolated from freshwater culture pond. J Microbiol Biotechnol 20, 1386-1392.

Collins, M. D. (1985). Isoprenoid quinone analysis in classification and identification. In Chemical Methods in Bacterial Systematics, pp. 267-287. Edited by M. Goodfellow \& D. E. Minnikin. London: Academic Press.

De Ley, J., Cattoir, H. \& Reynaerts, A. (1970). The quantitative measurement of DNA hybridization from renaturation rates. Eur $J$ Biochem 12, 133-142.

Dong, X.-Z. \& Cai, M.-Y. (2001). Determinative Manual for Routine Bacteriology. Beijing: Scientific Press (English translation).

Felsenstein, J. (1981). Evolutionary trees from DNA sequences: a maximum likelihood approach. J Mol Evol 17, 368-376.

Fitch, W. M. (1971). Towards defining the course of evolution: minimum change for a specific tree topology. Syst Zool 20, 406-416.

Fonnesbech Vogel, B., Venkateswaran, K., Christensen, H., Falsen, E., Christiansen, G. \& Gram, L. (2000). Polyphasic taxonomic approach in the description of Alishewanella fetalis gen. nov., sp. nov., isolated from a human foetus. Int J Syst Evol Microbiol 50, 1133-1142.

Gerhardt, P., Murray, R. G. E., Wood, W. A. \& Krieg, N. R. (editors) (1994). Methods for General and Molecular Bacteriology. Washington, DC: American Society for Microbiology.

Halpern, M., Senderovich, Y. \& Snir, S. (2007). Rheinheimera chironomi sp. nov., isolated from a chironomid (Diptera; Chironomidae) egg mass. Int J Syst Evol Microbiol 57, 1872-1875.

Hu, Y.-T., Zhou, P.-J., Zhou, Y.-G., Liu, Z.-H. \& Liu, S.-J. (2004). Saccharothrix xinjiangensis sp. nov., a pyrene-degrading actinomycete isolated from Tianchi Lake, Xinjiang, China. Int J Syst Evol Microbiol 54, 2091-2094.

Huß, V. A. R., Festl, H. \& Schleifer, K. H. (1983). Studies on the spectrophotometric determination of DNA hybridization from renaturation rates. Syst Appl Microbiol 4, 184-192.

Kates, M. (1986). Techniques of Lipidology, 2nd edn. Amsterdam: Elsevier.

Kim, M. S., Roh, S. W., Nam, Y. D., Chang, H. W., Kim, K. H., Jung, M. J., Choi, J. H., Park, E. J. \& Bae, J. W. (2009). Alishewanella jeotgali sp. nov., isolated from traditional fermented food, and emended description of the genus Alishewanella. Int J Syst Evol Microbiol 59, 2313-2316.

Kim, M. S., Jo, S. K., Roh, S. W. \& Bae, J. W. (2010). Alishewanella agri sp. nov., isolated from landfill soil. Int J Syst Evol Microbiol 60, 2199-2203.

Kumar, S., Tamura, K. \& Nei, M. (2004). MEGA3: integrated software for molecular evolutionary genetics analysis and sequence alignment. Brief Bioinform 5, 150-163.

Li, H. J., Zhang, X. Y., Zhang, Y. J., Zhou, M. Y., Gao, Z. M., Chen, X. L., Dang, H. Y. \& Zhang, Y. Z. (2011). Rheinheimera nanhaiensis sp. nov., isolated from marine sediments, and emended description of the genus Rheinheimera Brettar et al. 2002 emend. Merchant et al. 2007. Int J Syst Evol Microbiol 61, 1016-1022.

Marmur, J. \& Doty, P. (1962). Determination of the base composition of deoxyribonucleic acid from its thermal denaturation temperature. J Mol Biol 5, 109-118.

Merchant, M. M., Welsh, A. K. \& McLean, R. J. (2007). Rheinheimera texasensis sp. nov., a halointolerant freshwater oligotroph. Int J Syst Evol Microbiol 57, 2376-2380.

Pinhassi, J. \& Berman, T. (2003). Differential growth response of colonyforming $\alpha$ - and $\gamma$-proteobacteria in dilution culture and nutrient addition experiments from Lake Kinneret (Israel), the eastern Mediterranean Sea, and the Gulf of Eilat. Appl Environ Microbiol 69, 199-211. 
Poretsky, R. S., Bano, N., Buchan, A., LeCleir, G., Kleikemper, J., Pickering, M., Pate, W. M., Moran, M. A. \& Hollibaugh, J. T. (2005). Analysis of microbial gene transcripts in environmental samples. Appl Environ Microbiol 71, 4121-4126.

Roh, S. W., Nam, Y. D., Chang, H. W., Kim, K. H., Kim, M. S., Oh, H. M. \& Bae, J. W. (2009). Alishewanella aestuarii sp. nov., isolated from tidal flat sediment, and emended description of the genus Alishewanella. Int J Syst Evol Microbiol 59, 421-424.

Romanenko, L. A., Uchino, M., Falsen, E., Zhukova, N. V., Mikhailov, V. V. \& Uchimura, T. (2003). Rheinheimera pacifica sp. nov., a novel halotolerant bacterium isolated from deep sea water of the Pacific. Int J Syst Evol Microbiol 53, 1973-1977.

Ryu, S. H., Chung, B. S., Park, M., Lee, S. S., Lee, S. S. \& Jeon, C. O. (2008). Rheinheimera soli sp. nov., a gammaproteobacterium isolated from soil in Korea. Int J Syst Evol Microbiol 58, 2271-2274.

Saitou, N. \& Nei, M. (1987). The neighbor-joining method: a new method for reconstructing phylogenetic trees. Mol Biol Evol 4, 406-425.

Thompson, J. D., Gibson, T. J., Plewniak, F., Jeanmougin, F. \& Higgins, D. G. (1997). The CLUSTAL_X windows interface: flexible strategies for multiple sequence alignment aided by quality analysis tools. Nucleic Acids Res 25, 4876-4882.

Wu, C., Lu, X., Qin, M., Wang, Y. \& Ruan, J. (1989). Analysis of menaquinone compound in microbial cells by HPLC. Microbiology [English translation of Microbiology (Beijing)] 16, 176-178.

Yamamoto, S. \& Harayama, S. (1995). PCR amplification and direct sequencing of $g y r B$ genes with universal primers and their application to the detection and taxonomic analysis of Pseudomonas putida strains. Appl Environ Microbiol 61, 1104-1109.

Yoon, J.-H., Park, S. E., Kang, S.-J. \& Oh, T.-K. (2007). Rheinheimera aquimaris sp. nov., isolated from seawater of the East Sea in Korea. Int J Syst Evol Microbiol 57, 1386-1390.

Zhang, D., Yang, H., Zhang, W., Huang, Z. \& Liu, S.-J. (2003). Rhodocista pekingensis sp. nov., a cyst-forming phototrophic bacterium from a municipal wastewater treatment plant. Int J Syst Evol Microbiol 53, 1111-1114.

Zhang, X. X., Sun, L., Qiu, F. B., McLean, R. J. C., Jiang, R. B. \& Song, W. (2008). Rheinheimera tangshanensis sp. nov., a rice root-associated bacterium. Int J Syst Evol Microbiol 58, 2420-2424. 